Florida International University FIU Digital Commons

FCE LTER Journal Articles

FCE LTER

2009

\title{
Stable isotopes reveal complex changes in trophic relationships following nutrient addition in a coastal marine ecosystem
}

\author{
Anna R. Armitage \\ Department of Biological Sciences and Southeast Environmental Research Center, Florida International University, \\ armitage@fiu.edu \\ James W. Fourqurean \\ Department of Biological Sciences and Southeast Environmental Research Center, Florida International University, \\ fourqure@fiu.edu
}

Follow this and additional works at: https://digitalcommons.fiu.edu/fce_lter_journal_articles

\section{Recommended Citation}

Armitage, A.R., J.W. Fourqurean. 2009. Stable isotopes reveal complex changes in trophic relationships following nutrient addition in a coastal marine ecosystem. Estuaries and Coasts 32: 1152-1164.

This material is based upon work supported by the National Science Foundation through the Florida Coastal Everglades Long-Term Ecological Research program under Cooperative Agreements \#DBI-0620409 and \#DEB-9910514. Any opinions, findings, conclusions, or recommendations expressed in the material are those of the author(s) and do not necessarily reflect the views of the National Science Foundation. This work is brought to you for free and open access by the FCE LTER at FIU Digital Commons. It has been accepted for inclusion in FCE LTER Journal Articles by an authorized administrator of FIU Digital Commons. For more information, please contact dcc@fiu.edu, jkrefft@fiu.edu. 
Stable isotopes reveal complex changes in trophic relationships following nutrient addition in a coastal marine ecosystem

Anna R. Armitage ${ }^{1}$ and James W. Fourqurean ${ }^{2}$

${ }^{1}$ Corresponding author:

Department of Marine Biology

Texas A\&M University at Galveston

5007 Avenue U

Galveston, TX 77551

Email: armitaga@tamug.edu

Phone: 409-740-4842

Fax : 409-740-5002

${ }^{2}$ Department of Biological Sciences and Southeast Environmental Research Center

Marine Science Program

Florida International University

North Miami, FL 33181 


\begin{abstract}
Complex links between the top-down and bottom-up forces that structure communities can be disrupted by anthropogenic alterations of natural habitats. We used relative abundance and stable isotopes to examine changes in epifaunal food webs in seagrass (Thalassia testudinum) beds following six months of experimental nutrient addition at two sites in Florida Bay (USA) with different ambient fertility. At a eutrophic site, nutrient addition did not strongly affect food web structure, but at a nutrient-poor site, enrichment increased the abundances of crustacean epiphyte grazers, and the diets of these grazers became more varied. Benthic grazers did not change in abundance, but shifted their diet away from green macroalgae + associated epiphytes and towards an opportunistic seagrass (Halodule wrightii) that occurred only in nutrient addition treatments. Benthic predators did not change in abundance, but their diets were more varied in enriched plots. Food chain length was short and unaffected by site or nutrient treatment, but increased food web complexity in enriched plots was suggested by increasingly mixed diets. Strong bottom-up modifications of food web structure in the nutrient-limited site and the limited top-down influences of grazers on seagrass epiphyte biomass suggest that in this system, the bottom-up role of nutrient enrichment can have substantial impacts on community structure, trophic relationships, and, ultimately, the productivity values of the ecosystem.
\end{abstract}

Key words (6-10): Caridean, gastropod, palatability, shoalgrass, turtlegrass, epiphytes, nutrients 


\section{Introduction}

Substantial anthropogenic alterations of community structures have occurred through topdown (consumption) and bottom-up (resource availability) pathways. Exploitative grazer removal that leads to lethal overgrowths of weedy plants has been particularly well documented in coral reef ecosystems (Hughes 1994). In terrestrial habitats, hunting and habitat loss that diminishes top predator abundance can dramatically alter native vegetation communities (Berger et al. 2001). There is also evidence that anthropogenic nutrient enrichment has caused eutrophication in many ecosystems (Vitousek et al. 1997), though the outcome differs between terrestrial and aquatic habitats (Hillebrand et al. 2007). Aquatic systems generally receive more allochthonous nutrient input than terrestrial systems (Shurin et al. 2006), which can render coastal habitats susceptible to dominance by fast-growing, opportunistic primary producers (Fourqurean et al. 1995) and decreased producer diversity along urbanized and developed shorelines (Hauxwell et al. 2001). The ultimate impacts of both top-down and bottom-up anthropogenic alterations of aquatic habitats may be similar (Heck and Valentine 2006), leading to reduced biodiversity, dominance by opportunistic plant species, and altered consumer food webs.

Although consumers undeniably have important impacts on ecosystem structure (Hughes 1994), and consumer and resource controls on ecosystems are sometimes decoupled (Posey et al. 1999, Gruner 2004), the impacts of top-down and bottom-up forces are unlikely to act entirely independently (Polis 1999). Experimental work has demonstrated that complex interactions between consumers and nutrient supply influence primary producers in terrestrial mesocosms (Hartvigsen et al. 1995), cultivated grasslands (Dyer and Stireman 2003), and marine macroalgal assemblages (Russell and Connell 2005). Ultimately, top-down and bottom-up forces in 
communities are intricately linked (Worm et al. 2002), and understanding the impacts of a particular anthropogenic alteration, such as coastal nutrient enrichment, requires assessments of entire communities and the links within them.

Nutrient enrichment is well known to have large impacts on coastal ecosystem productivity, species composition, and primary producer biomass (e.g., Fourqurean et al. 1995, Lee and Dunton 2000). Mesocosm work has explored more complex effects of nutrients on upper trophic levels in a number of coastal habitats by manipulating consumer abundance in conjunction with nutrient supply (McGlathery 1995, Worm et al. 2002, Jaschinski and Sommer 2008). In situ field experiments have documented trophic responses to anthropogenic nutrient enrichment that include changes in faunal diet composition (Tewfik et al. 2005), increased food web complexity at moderate enrichment levels (Tewfik et al. 2007), or decreased food web complexity at high nutrient input rates (Tewfik et al. 2005, Singer and Battin 2007). Estuarine habitats are particularly susceptible to trophic alterations in response to anthropogenic nutrient input due to the close physical links to terrestrial habitats and input of terrestrial matter into estuarine food webs (Martinetto et al. 2006, Shurin et al. 2006).

Recent work in aquatic habitats has used stable isotopes $\left(\delta^{13} \mathrm{C}, \delta^{15} \mathrm{~N}\right)$ to compare food webs between eutrophic and oligotrophic habitats (Tewfik et al. 2005, Sierszen et al. 2006, Hadwen and Arthington 2007, Singer and Battin 2007). Although critical as foundation work, these comparative studies cannot definitively explain why food webs differ with nutrient supply, in part because enriched sites typically experience other anthropogenic impacts as well, including fishing pressure or upland development. Manipulative experimental work, especially at the community level, is necessary to define causal relationships and provide insight into the time scale and mechanisms driving nutrient-induced changes in coastal community trophic structure. 
Stable isotopes are a useful tool to assess changes in food webs and determine if consumer diets track nutrient-induced changes in primary producers (Fry and Sherr 1984). The few recent manipulative studies in mesocosms (Keats et al. 2004) and early experimental work (Peterson et al. 1993, Kling 1994) with stable isotopes have suggested intriguing links between food web structure and nutrient supply, but additional in situ work is needed to understand the dynamics and magnitude of these links.

Coastal seagrass beds are among the most vulnerable coastal habitats to anthropogenic impacts. In many areas, proximity to urbanized and cultivated terrestrial landscapes makes seagrass beds the first marine ecosystem to receive anthropogenically impacted runoff, which can subsequently alter vital ecological processes and economic functions of seagrass beds (Martinetto et al. 2006). In particular, disruption of trophic interactions can alter food web support for nurseries and fisheries that rely on seagrass beds (Harrigan et al. 1989) or reduce the capacity of epifauna to control algal proliferation following nutrient input (Hays 2005). Previous studies of nutrient enrichment impacts on seagrass beds have detected increases in epifauna, (Wootton et al. 1996, Gil et al. 2006), increased epiphyte loads (Short et al. 1995, Wear et al. 1999), and changes in seagrass canopy structural complexity (Fourqurean et al. 1995, Short et al. 1995). Trophic responses to experimental nutrient addition have been less thoroughly examined (but see Keats et al. 2004). Earlier segments of the current study revealed that epiphyte and epifauna abundances increased in response to nutrients (Gil et al. 2006), but the mechanism driving the changes was unclear: was there more food available, subsequently attracting more organisms ("resource rarity hypothesis," Peterson et al. 1993)? Alternatively, did nutrients modify primary producer composition by favoring fast-growing, opportunistic species and causing a shift in the bottom of the food web (Armitage and Fong 2004, Tewfik et al. 2005)? 
The overall goal of our study was to examine the impact of increased nutrient availability on food web structure. An ancillary objective was to improve seagrass ecosystem resource management by advancing the understanding of how seagrass food webs respond to nutrient enrichment. Because previous work has demonstrated that nutrient enrichment augmented fastgrowing species (microalgae and shoalgrass Halodule wrightii), particularly in a low-nutrient environment (Armitage et al. 2005, Gil et al. 2006) we hypothesized that nutrient-induced increases in grazer abundance would correspond with shifts in diet towards these prolific producers.

\section{Methods}

\section{Study design}

We examined the effects of nutrient enrichment on seagrass food webs in Florida Bay at two levels: (1) at two shallow ( $<2 \mathrm{~m})$ seagrass beds with varying species composition and background nutrient availability and (2) in response to experimental nutrient addition. The eastern site at Duck Key $\left(25^{\circ} 10.59^{\prime}\right.$ N, $80^{\circ} 29.39^{\prime}$ W) was characterized by a short Thalassia testudinum (turtle grass) canopy $(5.8 \pm 0.5 \mathrm{~cm})$ with low biomass $\left(12.4 \mathrm{~g} \pm 3.3 \mathrm{~g} / \mathrm{m}^{2}\right)$ and low calcareous green macroalgae (esp. Penicillus spp.) biomass $\left(<1 \mathrm{~g} / \mathrm{m}^{2}\right)$. Thalassia leaf tissue at Duck Key had a $\% \mathrm{~N}$ content of $1.92 \pm 0.06($ mean $\pm \mathrm{SE})$ and a $\% \mathrm{P}$ content of $0.047 \pm 0.004$, yielding a N:P ratio of approximately 92:1, suggesting severe phosphorus limitation (Armitage et al. 2005). The western site at Nine Mile Bank $\left(24^{\circ} 56.21^{\prime} \mathrm{N}, 80^{\circ} 51.65^{\prime} \mathrm{W}\right)$ was characterized by a taller Thalassia canopy $(10.1 \pm 0.4 \mathrm{~cm})$ with high biomass $\left(81.7 \pm 15.2 \mathrm{~g} / \mathrm{m}^{2}\right)$ and patchy calcareous green macroalgae (esp. Halimeda spp.) $\left(\sim 1 \mathrm{~g} / \mathrm{m}^{2}\right)$. Thalassia leaves at Nine Mile Bank had a $\% \mathrm{~N}$ content of $2.58 \pm 0.11$ and a $\% \mathrm{P}$ content of $0.086 \pm 0.007$, yielding an $\mathrm{N}: \mathrm{P}$ ratio of approximately 68:1 (Armitage et al. 2005). At both sites, $\% \mathrm{~N}$ content of Thalassia tissue was 
above the $1.8 \%$ threshold that suggests that $\mathrm{N}$ is limiting (Duarte 1990). Percent $\mathrm{P}$ content was nearly twice as high at Nine Mile Bank relative to Duck Key, suggesting more severe $\mathrm{P}$ limitation at Duck Key. Accordingly, previous enrichment experiments performed at these sites have unequivocally demonstrated strong short- and long-term responses to P enrichment at Duck Key, where $\mathrm{P}$ addition increased Thalassia and Halodule percent cover and productivity by approximately twofold (Armitage et al. 2005). In contrast, Thalassia beds at Nine Mile Bank showed few responses to P addition on the time scale of this study (Armitage et al. 2005).

In April 2004, twelve 2- $\mathrm{m}^{2}$ quadrats were demarcated with steel stakes in a grid at each site, with two meters between plots. Two treatments (control [C] and nutrient addition [nitrogen $(\mathrm{N})+$ phosphorus (P)]) were randomly assigned to the study plots ( $\mathrm{n}=6$ per site). The plots were fertilized bimonthly for six months with $\mathrm{N}$ as slow release nitrogen fertilizer (Polyon ${ }^{\top \mathrm{M}}$, Pursell Technologies Inc., $38 \% \mathrm{~N}$ ) and $\mathrm{P}$ as granular phosphate rock (Multifos ${ }^{\mathrm{TM}}$, IMC Global, $18 \% \mathrm{P}$ ) at loading rates of $1.43 \mathrm{~g} \mathrm{~N} \mathrm{~m}^{-2}$ day $^{-1}$ and $0.18 \mathrm{~g} \mathrm{P} \mathrm{m}^{-2}$ day $^{-1}$ based on maximum potential anthropogenic loading rates for the region (MCSM 2001). The fertilizer was sprinkled evenly on the plot and gently pressed into the sediment by hand. In carbonate environments like Florida Bay, dissolved inorganic phosphorus (DIP) quickly binds to particulate matter and settles to the substrate (de Kanel and Morse 1978). Owing to the rapid uptake of DIP by both inorganic and biotic processes, DIP concentrations in Florida Bay are always close to very low limits of detection; accordingly, organic and particulate forms of phosphorus are the dominant forms in the water column of the system (Fourqurean et al. 1993). Therefore, we assert that our fertilization protocol simulates the mechanism of phosphorus entry into the system. This protocol is effective in enriching benthic, seagrass, and epiphytic assemblages (Ferdie and Fourqurean 2004, Armitage et al. 2005). 
We concluded the experiment after six months in October 2004. This was adequate time to detect primary producer and epifauna density responses to nutrient enrichment (Gil et al. 2006). Leaf tissues of Thalassia, the slowest growing primary producer in our study plots, turn over at a rate of ca. $2 \%$ day $^{-1}$ (Zieman et al. 1989), so during the six months of our experiments, the above-ground seagrass biomass turned over completely. The turnover rate of many epifauna (Bauer and VanHoy 1996) are substantially less than six months, ensuring that tissue isotopic signatures would reflect diet changes (Post 2002a).

\section{Community characterization}

In October 2004, we collected seagrass and benthic epifauna using throw traps. A $1-\mathrm{m}^{2}$ throw trap with solid sides and a 2-mm mesh removable top was placed over each plot by a single snorkeler to minimize faunal disturbance. A pair of SCUBA divers then pulled sweep nets (2$\mathrm{mm}$ mesh) through the trap three times to collect benthic and seagrass-associated epifauna. Two divers performed all sweeps to standardize collection effort. Samples were frozen $\left(-20^{\circ} \mathrm{C}\right)$ until further analysis. In the laboratory, fauna were separated from plant and sediment debris, identified to the lowest practical identification level (most often to species), enumerated, and dried at $60^{\circ} \mathrm{C}$. Epifauna densities and species composition are reported in Gil et al. (2006), and a summary of the densities of the main producer and faunal groups is presented in Table 1.

Variances in the densities of each epifaunal group were standardized by calculating $z$ scores. Differences in community composition between sites and enrichment treatments were evaluated using linear discriminant function analysis (DFA) where the predictor variables were the densities of each epifaunal group as defined by Gil et al. (2006), excluding benthic gastropods, which were not found at Nine Mile Bank. We plotted significant discriminant functions (eigen value $>1$ ) to illustrate distinctions among groups. To assess the potential for the most common 
epiphyte grazers to regulate epiphytic growth on seagrasses in enriched conditions, we performed linear regressions separately at each site, where the dependent variables were Thalassia testudinum epiphyte biomass (chlorophyll $a$ concentration) and the independent variables were epiphyte-grazing crustacean densities.

Stable isotope analysis

Gastropods, bivalves, and crabs were dissected prior to drying; only soft tissue was retained for stable isotopic analyses. Large shrimp (primarily Farfantepenaeus duorarum) were bisected behind the thorax; only the posterior section (muscle and shell) was retained for analysis. Dorsoventral sections of fish were removed for analysis whenever possible. Exceptions were very small fish such as the dwarf sea horse Hippocampus zosterae, in which case entire specimens were retained. Whole bodies of all other organisms were kept for analyses. All animal tissue was dried, ground, and homogenized prior to stable isotopic analyses.

We also collected plant and sediment samples to characterize producer isotopic signatures. Between two and ten seagrass short shoots and at least one macroalgal thallus of each species were collected per plot (the quantity collected varied with species based on leaf or thallus size). Approximately six detrital seagrass leaves of each species were also collected from each plot. Epiphytes were removed from live seagrass leaves by gently scraping with a razor blade; detrital seagrass leaves were not cleaned. Macroalgal thalli were rinsed to remove adhered sediments, but the complex blade structures did not permit complete epiphyte removal; therefore associated epiphytes were included with the macroalgal tissue samples. A single sediment core $(5-\mathrm{cm}$ diameter, 2-cm deep) was collected from the center of each plot. All plant tissue, detritus, and sediments were dried, ground and homogenized prior to stable isotopic analyses. 
In order to remove carbonate material from the samples, all samples were acidified in a $\mathrm{HCl}$ fume bath for $>7$ days prior to isotopic analyses. We found that acidification caused an unpredictable amount of variation in $\delta^{15} \mathrm{~N}$ signatures among various test plant and animal samples; we therefore obtained $\delta^{15} \mathrm{~N}$ signatures from untreated samples and $\delta^{13} \mathrm{C}$ signatures from fumed samples. We also measured the $\delta^{15} \mathrm{~N}$ signature of unused nitrogen fertilizer to confirm the expected value near atmospheric nitrogen (average $\delta^{15} \mathrm{~N}=-0.08 \% \pm 0.03 \mathrm{SE}, \mathrm{n}=3$ ).

All isotopic measurements were performed with standard elemental analyzer isotope ratio mass spectrometer (EA-IRMS) procedures using a Finnigan MAT Delta C IRMS continuous flow system at the Southeast Environmental Research Center at Florida International University. The samples' isotopic ratios $(\mathrm{R})$ are reported in the standard delta notation: $\delta(\%)=$ $\left[\left(\mathrm{R}_{\text {sample }} / \mathrm{R}_{\text {standard }}\right)-1\right] \times 1,000 \%$. These results are presented with respect to the international standards of atmospheric nitrogen (AIR, $\mathrm{N}_{2}$ ) and Vienna Pee Dee belemnite (V-PDB) for carbon using the secondary standards IAEA N-3 for $\delta^{15} \mathrm{~N}$ and IAEA CH-6 for $\delta^{13} \mathrm{C}$. Analytical reproducibility of the reported $\delta$ values, based on sample replicates, was better than $\pm 0.2 \%$ for $\delta^{15} \mathrm{~N}$ and $\pm 0.08 \%$ for $\delta^{13} \mathrm{C}$.

Carbon and nitrogen contents of each of the producer and consumer species were determined separately using a $\mathrm{CHN}$ analyzer (Fisons NA1500). All samples were ashed at $500^{\circ} \mathrm{C}$ for three hours to remove organic carbon and reanalyzed for carbon content to allow for calculation of the organic carbon content of the original samples.

For analyses of epifaunal diets, we combined consumers and producers into trophic groups based on taxonomic and isotopic similarities. We divided primary producers into eight groups: (1) Thalassia testudinum live tissue and detritus, (2) Halodule wrightii live tissue and detritus, (3) Halimeda spp. (green macroalgae) and associated epiphytes, (4) other calcareous green 
macroalgae (Penicillus spp., Acetabularia sp., Batophora occidentalis) and associated epiphytes, (5) Laurencia spp. (red macroalgae), (6) Hypnea spp. (red macroalgae), (7) Thalassia epiphytes, and (8) benthic microalgal and detrital sediment-associated assemblage (hereby "microbenthos"). Consumers were divided into four groups: (1) epiphyte grazers (crustaceans and gastropods), (2) benthic grazers (gastropods), (3) omnivores and scavengers (crabs), and (4) predators (fish, crustaceans, and gastropods).

In order to determine the relative importance of food sources to consumers in each nutrient treatment and at each site, we constructed dual isotope graphs for visual assessments and used two mixing model techniques. We first calculated diet contributions with a simple linear mixing model modified for multiple sources using IsoSource v.1.3.1 software (Phillips and Gregg 2003). Not all consumer or producer groups were found in each study plot, so we pooled all consumer signatures for each nutrient treatment at each site and generated two estimates of diet composition per site: one for each nutrient treatment. Trophic isotope fractionation values in this system are largely unknown, and published values range from +0 to $5 \%$ for $\delta^{13} \mathrm{C}$ and +2 to $4 \%$ o for $\delta^{15}$ N (e.g., Fry and Sherr 1984, Phillips and Koch 2002, Post 2002a). Based on studies in similar systems, we assumed intermediate fractionation values of $+1.0 \%$ for $\delta^{13} \mathrm{C}$ (Fry and Sherr 1984 ) and $+3.5 \%$ for $\delta^{15} \mathrm{~N}$ (Post 2002b) per trophic level. All predators had very similar isotopic signatures, so we assumed that all the predators we captured had similar diets composed of primary consumers (grazers).

Based on the outcome of the simple mixing models, we entered the three most important food sources into a concentration-dependent mass balance mixing model, which assumes that the contribution of a particular food source is proportional to the elemental C and N concentration in that food source (Phillips and Koch 2002). If the three included food sources did not produce a 
model fit, then we subdivided pooled food groups (e.g., green macroalgae) into individual species (e.g., Batophora, Acetabularia, Penicillus). Trophic level stable isotopic fractionation values in aquatic systems are variable (Vander Zanden and Rasmussen 2001), and are largely unknown in Florida Bay for the species we encountered. Therefore, because we assumed that we sampled all probable food sources, if the fractionation values previously used in the simple linear mixing model (see above) did not allow for a model fit, we made slight $( \pm 1.0 \%$ o adjustments of the trophic correction (Vander Zanden and Rasmussen 2001). These model calculations were performed for epiphyte grazer, benthic grazer (excluding Nine Mile Bank due to insufficient tissue availability), and predator trophic groups. We were not confident that we fully sampled all potential food sources for the omnivore/scavenger trophic group; therefore we limit our conclusions about their diets to absolute changes in $\delta^{13} \mathrm{C}$ and $\delta^{15} \mathrm{~N}$ values among treatments.

Incorrect assumptions about fractionation values could shift model predictions, so we have included results from all three techniques (visual assessments, linear mixing models, and concentration dependent mixing models) in order to provide a more comprehensive assessment of the relative importance of each food source to consumers.

The effects of nutrient enrichment and site on isotopic signatures within each consumer group were determined using unpaired t-tests (for consumer groups located only at one site or in one nutrient treatment) or two-way ANOVA, where enrichment and site were considered fixed factors. Variances of all data were tested for homoscedasticity using the $F_{\max }$ test. In cases where $\log$ transformation was unable to homogenize variances, a non-parametric Mann-Whitney U test or a Kruskal-Wallis test was used to compare means.

Because not all grazers and not all predators were present in all plots, we were not able to calculate food chain length in each study plot, so we bootstrapped estimates of food chain length. 
We assumed that we collected a representative subsample of the grazer and predator populations and used the population mean and standard deviation to generate normal distributions of 1000 random grazer and predator $\delta^{15} \mathrm{~N}$ values for each site and nutrient treatment. We randomly paired predator and grazer $\delta^{15} \mathrm{~N}$ values from this distribution and estimated food chain length by calculating the difference between the two values. We calculated the $95 \%$ confidence interval of the 1000 food chain lengths produced for each site and nutrient treatment as the interval between the $2.5^{\text {th }}$ and $97.5^{\text {th }}$ percentiles. Longer food chain lengths suggest a higher number of trophic steps and therefore increased trophic complexity.

\section{Results}

\section{Community characterization}

Linear DFA produced two significant (eigen value $>1$ ) discriminant functions (DF) that revealed clear differences in epifaunal communities among sites and enrichment treatments. The first DF was driven by differences between sites (Fig. 1) and explained $82 \%$ of the variability in the community composition. The abundances of predatory crustaceans and "other" epifauna (primarily bivalves and holothurians) were most strongly correlated with DF1 (Table 2).

Predatory crustaceans were more abundant at Nine Mile Bank, and other epifauna were more abundant at Duck Key (Fig. 2). The second DF was driven by enrichment effects (Fig. 1) and explained an additional $15 \%$ of the variability. The abundances of epiphyte grazing crustaceans

and predatory fish were most strongly correlated with DF2; both were more abundant in enriched plots, though the magnitude of the increase in predatory fish density was small relative to the increase in epiphyte grazing crustaceans (Table 1, Fig. 2). Epiphyte grazing gastropods, omnivores, and other (non-fish) predators did not strongly vary with site or nutrient treatment. 
Benthic grazing gastropods were excluded from the DFA because they were not present at Nine Mile Bank, but they showed no density response to enrichment (Gil et al. 2006).

Linear regressions revealed that epiphyte-grazing crustacean density and Thalassia testudinum epiphyte biomass were positively related to each other at the nutrient poor site, Duck Key $\left(p=0.020, r^{2}=0.433\right)$, suggesting bottom-up control of crustacean grazer densities. At Nine Mile Bank, there was no significant relationship between epiphyte-grazing crustacean density and epiphyte biomass.

Details on epifaunal species composition and densities from this study are reported in Gil et al. (2006) and summarized in Table 1; relevant results based on the DFA are presented here. At Duck Key, total epifaunal density was higher in enriched than in control plots, and the largest increases in density occurred in crustacean epiphyte grazers (primarily caridean shrimp, grazing isopods, and gammarid amphipods; Fig. 2). Most other epifaunal groups, including benthic grazing gastropods, did not change in abundance following enrichment. Likewise, at Nine Mile Bank, total epifaunal density was higher in enriched than in control plots, and the largest increases in density occurred in crustacean epiphyte grazers (Fig. 2), although at this site, the ANOVA analysis from Gil et al. (2006) suggested that the mean densities were not significantly affected by fertilization, possibly due to low power.

Stable isotope analysis

Plant $\delta^{13} \mathrm{C}$ signatures were enriched at Nine Mile Bank relative to Duck Key for Thalassia epiphytes and microbenthos (Fig. 3, Table 3). A non-parametric Kruskal-Wallis test performed on Thalassia $\delta^{13} \mathrm{C}$ signatures indicated a similar difference between sites $(\mathrm{H}=21.485, \mathrm{p}<$ 0.0001). There were insufficient replicate Halodule tissue samples for statistical analysis, but 
$\delta^{13} \mathrm{C}$ signatures appeared to be similar between sites (Fig. 3). There were no nutrient effects on $\delta^{13} \mathrm{C}$ producer signatures and no interactions between factors.

Plant $\delta^{15} \mathrm{~N}$ signatures were more enriched at Duck Key relative to Nine Mile Bank for Thalassia, Thalassia epiphytes, and microbenthos (Fig. 3, Table 3). There were insufficient replicate Halodule, Laurencia, and Hypnea tissue samples for statistical analysis, but a similar qualitative trend emerged for Laurencia. Nutrient addition significantly lowered $\delta^{15} \mathrm{~N}$ signatures in Thalassia and green macroalgae + associated epiphytes at both sites, likely because of the low $\delta^{15} \mathrm{~N}$ of the nitrogen fertilizer. Halimeda showed a similar pattern at the one site where it was found, Nine Mile Bank (unpaired $t$-test, $\mathrm{t}=-8.281, \mathrm{p}=0.0036$ ). A significant site*nutrient interaction for Thalassia epiphytes stemmed from the large nutrient-induced decrease in the $\delta^{15} \mathrm{~N}$ signature at Nine Mile Bank but a relatively small change at Duck Key.

Epiphyte grazer, omnivore, and predator $\delta^{13} \mathrm{C}$ signatures were enriched at Nine Mile Bank relative to Duck Key (Fig. 3, Table 4). There were no nutrient effects on $\delta^{13} \mathrm{C}$ consumer signatures and no interactions between factors. There was insufficient benthic grazer tissue for analysis at Nine Mile Bank, and an unpaired t-test comparing nutrient treatment effects on benthic grazer $\delta^{13} \mathrm{C}$ signatures within Duck Key did not reveal a significant treatment effect $(\mathrm{t}=$ $1.379, \mathrm{p}=0.2011)$

Epiphyte grazer, omnivore, and predator $\delta^{15} \mathrm{~N}$ signatures were significantly more enriched at Duck Key relative to Nine Mile Bank (Fig. 3, Table 4). In addition, nutrient addition significantly lowered $\delta^{15} \mathrm{~N}$ signatures for epiphyte grazers and omnivores. There were no significant interactions between factors. A Mann-Whitney U test comparing nutrient treatment effects on benthic grazer $\delta^{15} \mathrm{~N}$ signatures within Duck Key revealed significantly lower $\delta^{15} \mathrm{~N}$ in enriched relative to control plots $(Z=-2.646, \mathrm{p}=0.0082)$. 
Dual isotope graphs and standard linear mixing models suggested that epiphyte grazer diets were similar between enriched and control treatments at Duck Key, and were primarily composed of green macroalgae and associated epiphytes (Figs. 3, 4). At Duck Key, concentration dependent mixing models did not provide a model fit when the producer groups described in Table 4 were used; therefore, the concentration dependent models used genera (Batophora, Acetabularia, and Penicillus) within the most important group from the linear mixing model, "Other calcareous green macroalgae." This model suggested that at Duck Key, epiphyte grazers selected primarily Acetabularia and associated epiphytes in control plots and consumed more Batophora and associated epiphytes in enriched plots (Fig. 3, Table 5).

Standard linear mixing models suggested that epiphyte grazer diets at Nine Mile Bank were more mixed among all producer groups than at Duck Key, with microbenthos composing a larger segment of their diet in control plots than in enriched plots (Figs. 3, 4). Concentration dependent mixing models indicated that in control plots at Nine Mile Bank, epiphyte grazers primarily consumed Halimeda and associated epiphytes and secondarily consumed microbenthos. In enriched plots, their diets were more evenly mixed between Halodule and all calcareous green macroalgae and associated epiphytes (Fig. 3, Table 5).

Standard linear mixing models suggested that benthic grazer diets were different between control and enriched plots at Duck Key. In control plots, benthic grazer diets were primarily composed of green macroalgae and associated epiphytes (Figs. 3, 4). In enriched plots, benthic grazer diets shifted to Halodule. Concentration dependent mixing models at Duck Key were inconclusive, as no combination of three food sources produced a model fit. Benthic grazer diets may have been exclusively composed of Halodule tissue, or we may have missed a food source 
(e.g., detritus) for the benthic grazers, or the trophic fractionation values for these consumers may not match the published values that we used in our models.

At Nine Mile Bank, the stable isotope data suggested that benthic grazers in enriched plots consumed Hypnea sp. and green macroalgae + associated epiphytes (Figs. 3, 4). There was insufficient benthic grazer tissue for analysis in control plots at Nine Mile Bank, and insufficient plant tissue for the concentration dependent mixing models in both nutrient treatments.

Standard linear mixing models suggested that predator diets were mixed in all treatments and sites (Fig. 5). Isopods constituted the largest component of predator diets in enriched plots at Duck Key and were small diet components at Nine Mile Bank. Diets at Nine Mile Bank were more heavily dependent on larger omnivores and scavengers such as hermit crabs and other decapod crabs. Concentration dependent mixing models suggested that at both sites, predators tended to specialize on specific food items in control plots (grazing crustaceans at Duck Key and hermit crabs at Nine Mile Bank; Table 5). In enriched plots, predator diets were more mixed between hermit crabs, grazing crustaceans, and grazing snails.

Average food chain length at Duck Key, as represented by the absolute difference between grazer and producer $\delta^{15} \mathrm{~N}$ signatures, was not substantially different between nutrient treatments because of substantial overlap in the $95 \%$ confidence intervals $(\mathrm{CI})$ (control mean $=3.5 \% 0 \delta^{15} \mathrm{~N}$ difference between grazers and predators, $95 \% \mathrm{CI}=1.6$ to $5.2 \%{ }_{0} \delta^{15} \mathrm{~N}$; enriched: mean $=4.5 \%$ $\delta^{15} \mathrm{~N}, 95 \% \mathrm{CI}=0.5$ to $8.3 \% \delta^{15} \mathrm{~N}$ ). Likewise, at Nine Mile Bank, mean food chain length was similar between nutrient treatments (control mean $=1.8 \%{ }_{0} \delta^{15} \mathrm{~N}, 95 \% \mathrm{CI}=-0.5$ to $4.1 \%{ }_{0} \delta^{15} \mathrm{~N}$; enriched: average $=2.2 \%{ }_{0}^{15} \mathrm{~N}, 95 \% \mathrm{CI}=-1.0$ to $\left.5.6 \% \delta^{15} \mathrm{~N}\right)$. 


\section{Discussion}

In this study, we examined how altered consumer diets might have influenced density responses to nutrient enrichment: did the consumers respond to increased food availability (Peterson et al. 1993), or was food composition modified by nutrients (Armitage and Fong 2004, Tewfik et al. 2005)? Overall, diet shifts did not reflect changes in consumer abundance. The consumers with the largest increases in density, such as grazing crustaceans, did not substantially change their diet in enriched plots. Benthic grazers (primarily gastropods), which were more abundant at the nutrient-poor site but did not increase in density following nutrient addition, shifted away from a macroalgal-based diet and consumed more live or detrital Halodule tissue in enriched plots. Similar nutrient-induced shifts between food sources have been documented in other benthic marine habitats (Tewfik et al. 2005) and are likely to also occur in terrestrial habitats where opportunistic, palatable plant species proliferate under enriched conditions (Baer et al. 2004). The thin leaves of Halodule and its rapid proliferation in enriched conditions (Fourqurean et al. 1995) suggest that it may be more palatable than Thalassia, and field experiments have confirmed that Halodule transplants are rapidly consumed by grazers (Armitage and Fourqurean 2006). Benthic grazers such as gastropods can easily access Halodule leaves emerging from the substrate, and it is likely that these grazers readily consumed this new, abundant, palatable food source in enriched conditions. Concentration-dependent mixing models suggested more complex changes in diets across other consumer groups, with a general nutrientinduced increase in diet diversity within the predator group and, to a lesser degree, the epiphyte grazers. Few other studies have documented this trophic group-level shift towards more mixed diets with nutrient enrichment, although some individual species within Ruppia maritima beds in mesocosms displayed similar patterns (Keats et al. 2004). 
We did not detect any difference in food chain length between nutrient treatments or sites. Although the hypothesis that there is a positive relationship between productivity and food chain length has not been well supported experimentally in natural communities (e.g., Briand and Cohen 1987, Post 2002a), microcosm work suggests that in severely resource-limited conditions, food chains become longer as resource availability increases (Kaunzinger and Morin 1998). Duck Key is severely phosphorus limited (Fourqurean and Zieman 2002, Armitage et al. 2005), suggesting that enrichment should have increased food chain length at that site. However, we could not detect nutrient effects on food chain length with any statistical confidence, possibly because the food chains within the epifauna community appeared to be very short. Food chain length, as represented by the difference in $\delta^{15} \mathrm{~N}$ signatures between predators and grazers, ranged from 1.8 to $4.5 \% \delta^{15} \mathrm{~N}$. Assuming a fractionation rate of $3.5 \% 0 \delta^{15} \mathrm{~N}$, these values suggest that there was only one (or less) trophic step between the predators and grazers we collected. Longer food chains may have been detected if we had collected more mobile consumers that presumably occupy higher trophic levels. Within the benthic epifauna community that we studied, the food web consisted of short food chains in all treatments; therefore, food chain length does not accurately represent trophic complexity in this system.

Species diversity and richness display positive responses to nutrient enrichment in some marine ecosystems, particularly in low-productivity sites (Worm et al. 2002). Previous experimental work in seagrass beds, however, suggests that diversity responses to enrichment more closely resemble terrestrial systems (Hillebrand et al. 2007), with a decrease in faunal diversity and the ultimate simplification of food webs and shortened food chain length (Tewfik et al. 2005, Singer and Battin 2007, Tewfik et al. 2007). Although we observed increases in epifaunal density and biomass in this study, we did not detect any significant impact of 
enrichment on epifaunal diversity (Gil et al. 2006). The relatively small scale of this study (2- $\mathrm{m}^{2}$ plots) limited our ability to collect all consumers within the epifaunal community, and does not allow us to draw conclusions about larger, more mobile consumers that may have grazed partially in and partially outside of the plots. Despite the plot size limitations, our results indicate that enrichment increased the variety of food items consumed by epifaunal within trophic levels, presenting an intriguing contrast to previous seagrass studies that suggest enrichment decreases food web complexity (Tewfik et al. 2005). It is possible that nutrient limitation was so extreme at Duck Key that nutrient availability was constraining diet composition, and that our experimental fertilization constituted an intermediate enrichment level (sensu Tewfik et al. 2007) that released the severe bottom-up controls on the seagrass epifaunal community by increasing the availability or palatability of a wider range of food sources.

Few previous studies have experimentally evaluated nutrient impacts on seagrass food webs; most have examined trophic relationships in areas with differing amounts of anthropogenic nutrient input (Tewfik et al. 2005, Hadwen and Arthington 2007). In cases where aquatic food webs were supported mainly by autochthonous sources that were subsidized but not compositionally changed by nutrient enrichment, there were few changes in trophic structure (Sierszen et al. 2006, Hadwen and Arthington 2007). In a system where allochthonous enrichment changed producer composition, there was a large food web response, with a general loss of diversity and a shift towards generalist urchin consumers (Tewfik et al. 2005). In one of the few experimental studies evaluating enrichment effects on seagrass epifaunal food webs, a similar shifts towards generalist deposit feeders occurred (Keats et al. 2004). Our study system displayed both of these types of changes - subsidization of existing producers and the proliferation of new producers. The downward shift of most producer and consumer $\delta^{15} \mathrm{~N}$ 
signatures in enriched plots as a consequence of adding a $0 \% \delta^{15} \mathrm{~N}$ fertilizer to all enriched plots suggests subsidization of existing food sources, and some consumers, such as grazing crustaceans, continued to eat those same producers. We also detected increases in the opportunistic seagrass Halodule, and some consumer groups, namely benthic grazers, shifted their diets to that new food source.

The two study sites differed substantially in nutrient availability (Fourqurean and Zieman 2002, Armitage et al. 2005), but plant and animal species compositions were also substantially different between sites (Gil et al. 2006). The local species pool likely influenced the response of epifaunal food webs to nutrient enrichment. By experimentally adding nutrients to study plots at these two sites, we were able to detect community-level shifts in food webs that would not have been apparent from a comparison between two sites that differed markedly in nutrient availability but also differed in community composition and other abiotic characteristics. More complex and varied diets and altered epifaunal community composition are potential outcomes following nutrient enrichment into the Florida Bay ecosystem, though these changes depend on ambient resource levels.

Under eutrophic conditions, grazers such as caridean shrimp have been shown to control epiphytic overgrowth of seagrasses in some systems (Drury-McCall and Rakocinski 2007, Jaschinski and Sommer 2008). Although we detected higher densities of epiphyte-grazing crustaceans in enriched plots, there was also higher epiphyte biomass in those plots, suggesting bottom-up control of grazer densities. The dietary analyses from this study suggest that although the grazing crustaceans increased in density in nutrient addition plots, they maintained similar diets under enriched conditions and thus did not consume the opportunistic producers that proliferated. In fact, the isotopic analyses suggest that few of the grazers in this system 
consumed Thalassia testudinum epiphytes as a primary food source; they appeared to prefer the epiphytes associated with macroalgal thalli. Therefore, the ability of epiphyte grazers to control epiphyte overgrowth on seagrasses in this nutrient-limited system may be minimal. Benthic grazers, in contrast, selected opportunistic producers in enriched plots and may have a larger role in regulating producer communities in nutrient-limited habitats.

The simple and concentration-dependent mixing models both suggested that although Thalassia testudinum was consumed, it was not the primary dietary component of any of the trophic groups and was therefore not an important source of food web support for the benthic epifaunal community, despite the fact that $T$. testudinum is the most common primary producer and the major structuring element of the seagrass beds we studied. Although seagrass tissue is likely an important food source for larger, more motile grazers (Heck and Valentine 2006), seagrass epiphytes typically support epifaunal grazers (Keats et al. 2004, Jaschinski and Sommer 2008). The primary source of food web support in our study was green macroalgae and associated epiphytes. The green macroalgae largely consisted of calcified genera including Penicillus spp., Acetabularia sp., and Batophora occidentalis. With the exception of the lightly calcified Batophora, these macroalgal species are probably not edible by small grazers like caridean shrimp. Rather, it is more likely that these grazers utilized the complex macroalgal structure (Parker et al. 2001) and consumed the microalgal epiphytes associated with the macroalgae.

Consumer and resource controls on communities can be closely linked through trophic cascades, but in many ecosystems, top-down and bottom-up forces are decoupled (Posey et al. 1999, Gruner 2004) or linked through a series of more complex interactions (Hartvigsen et al. 1995, Dyer and Stireman 2003, Russell and Connell 2005). Herbivory effects on oligotrophic 
seagrass systems are predicted to be important (Heck and Valentine 2006, Hillebrand et al. 2007), but we did not detect strong consumer effects, nor did we see evidence of top-down control within the epifaunal community in the form of a trophic cascade. Increased caridean shrimp abundance in enriched plots might have been able to control epiphytic growth (DruryMcCall and Rakocinski 2007, Jaschinski and Sommer 2008). However, our stable isotopic analyses suggest that grazer diets were primarily composed of green macroalgae and associated epiphytes, not Thalassia epiphytes. Therefore, the top-down influences of grazers on this seagrass community appear to be minor in comparison with the strong bottom-up influence of nutrient supply. In a historical context, macroherbivores (e.g., turtles, manatees) have had strong top-down influences on seagrass communities in the past (Heck and Valentine 2006), but when macroherbivores are reduced or absent, the bottom-up role of anthropogenic nutrient enrichment increases in relative importance.

\section{Acknowledgements}

This research was funded by a grant from the Everglades National Park (ENP) under cooperative agreement 1443CA528001022 and by the Florida Coastal Everglades Long Term Ecological Research Program funded by the US National Science Foundation (Cooperative Agreement \#DEB-9910514). Doug Morrison and Bill Perry facilitated permit issuance and use

of ENP facilities. United States Geological Survey Biological Research Division East, especially Mike Robblee, Andy Davis, Dave Reed, and Travis Thyberg, assisted with throw trap operation and faunal identification. We are grateful to Melissa Gil, Bryan Dewsbury, Susie Escorcia, Tom Frankovich, Jeremy Stalker, and Pascale William for devoting field and laboratory time to this project. Stable isotope analyses were performed at the FIU Stable Isotope Laboratory under the direction of W.A. Anderson. Pursell Technologies Inc. and IMC Global generously donated the 
nitrogen and phosphorus fertilizers, respectively, for this study. This is contribution number XXX from the Southeast Environmental Research Center at FIU.

\section{References}

Armitage, A.R. and P. Fong. 2004. Upward cascading effects of nutrients: shifts in a benthic microalgal community and a negative herbivore response. Oecologia 139:560-567.

Armitage, A.R. and J.W. Fourqurean. 2006. The short-term influence of herbivory near patch reefs varies between seagrass species. Journal of Experimental Marine Biology and Ecology 339:65-74.

Armitage, A.R., T.A. Frankovich, K.L. Heck, Jr., and J.W. Fourqurean. 2005. Experimental nutrient enrichment causes complex changes in seagrass, microalgae, and macroalgae community structure in Florida Bay. Estuaries 28:422-434.

Baer, S.G., J.M. Blair, S.L. Collins, and A.K. Knapp. 2004. Plant community responses to resource availability and heterogeneity during restoration. Oecologia 139:617-629.

Bauer, R.T. and R. VanHoy. 1996. Variation in sexual systems (protandry, gonochorism) and reproductive biology among three species of the shrimp genus Thor (Decapoda: Caridea). Bulletin of Marine Science 59:53-73.

Berger, J., P.B. Stacey, L. Bellis, and M.P. Johnson. 2001. A mammalian predator-prey imbalance: grizzly bear and wolf extinction affect avian neotropical migrants. Ecological Applications 11:947-960.

Briand, F. and J.E. Cohen. 1987. Environmental correlates of food chain length. Science 238:956-960. 
de Kanel, J. and J.W. Morse. 1978. The chemistry of orthophosphate uptake from seawater on to calcite and aragonite. Geochimica et Cosmochimica Acta 42:1335-1340.

Drury-McCall, D. and C.F. Rakocinski. 2007. Grass shrimp (Palaemonetes spp.) play a pivotal trophic role in enhancing Ruppia maritima. Ecology 88:618-624.

Duarte, C.M. 1990. Seagrass nutrient content. Marine Ecology Progress Series 67:201-207.

Dyer, L.A. and J.O. Stireman, III. 2003. Community-wide trophic cascades and other indirect interactions in an agricultural community. Basic and Applied Ecology 4:423-432.

Ferdie, M. and J.W. Fourqurean. 2004. Responses of seagrass communities to fertilization along a gradient of relative availability of nitrogen and phosphorus in a carbonate environment. Limnology and Oceanography 49:2082-2094.

Fourqurean, J.W., M.J. Durako, M.O. Hall, and L.N. Hefty. 2002. Seagrass distribution in South Florida: a multi-agency coordinated monitoring program. In The Everglades, Florida Bay, and coral reefs of the Florida Keys: an ecosystem sourcebook, ed.^eds. J.W. Porter and K.G. Porter, 497-522. Boca Raton: CRC Press.

Fourqurean, J.W., R.D. Jones, and J.C. Zieman. 1993. Processes influencing water column nutrient characteristics and phosphorus limitation of phytoplankton biomass in Florida Bay, FL, USA: inferences from spatial distributions. Estuarine, Coastal and Shelf Science 36:295314.

Fourqurean, J.W., G.V.N. Powell, W.J. Kenworthy, and J.C. Zieman. 1995. The effects of longterm manipulation of nutrient supply on competition between the seagrasses Thalassia testudinum and Halodule wrightii in Florida Bay. Oikos 72:349-358. 
Fourqurean, J.W. and J.C. Zieman. 2002. Nutrient content of the seagrass Thalassia testudinum reveals regional patterns of relative availability of nitrogen and phosphorus in the Florida Keys USA. Biogeochemistry 61:229-245.

Fry, B. and E.B. Sherr. 1984. $\delta^{13}$ C measurements as indicators of carbon flow in marine and freshwater ecosystems. Contributions in Marine Science 27:13-47.

Gil, M., A.R. Armitage, and J.W. Fourqurean. 2006. Nutrient impacts on epifaunal density and species composition in a subtropical seagrass bed. Hydrobiologia 569:437-447.

Gruner, D.S. 2004. Attenuation of top-down and bottom-up forces in a complex terrestrial community. Ecology 85:3010-3022.

Hadwen, W.L. and A.H. Arthington. 2007. Food webs of two intermittently open estuaries receiving ${ }^{15} \mathrm{~N}$-enriched sewage effluent. Estuarine, Coastal and Shelf Science 71:347-358.

Harrigan, P., J.C. Zieman, and S.A. Macko. 1989. The base of nutritional support for the gray snapper Lutjanus griseus: an evaluation based on a combined stomach content and stable isotope analysis. Bulletin of Marine Science 44:65-77.

Hartvigsen, G., D.A. Wait, and J.S. Coleman. 1995. Tri-trophic interactions influenced by resource availability: predator effects on plant performance depend on plant resources. Oikos 74:463-468.

Hauxwell, J., J. Cebrian, C. Furlong, and I. Valiela. 2001. Macroalgal canopies contribute to eelgrass (Zostera marina) decline in temperate estuarine ecosystems. Ecology 82:1007-1022.

Hays, C.G. 2005. Effect of nutrient availability, grazer assemblage and seagrass source population on the interaction between Thalassia testudinum (turtle grass) and its algal epiphytes. Journal of Experimental Marine Biology and Ecology 314:53-68. 
Heck, K.L., Jr. and J.F. Valentine. 2006. Plant-herbivore interactions in seagrass meadows. Journal of Experimental Marine Biology and Ecology 330:420-436.

Hillebrand, H., D.S. Gruner, E.T. Borer, M.E.S. Bracken, E.E. Cleland, J.J. Elser, W.S. Harpole, J.T. Ngai, E.W. Seabloom, J.B. Shurin, and J.E. Smith. 2007. Consumer versus resource control of producer diversity depends on ecosystem type and producer community structure. Proceedings of the National Academy of Sciences of the United States of America 104:10904-10909.

Hughes, T.P. 1994. Catastrophes, phase shifts, and large-scale degradation of a Caribbean coral reef. Science 265:1547-1551.

Jaschinski, S. and U. Sommer. 2008. Top-down and bottom-up control in an eelgrass-epiphyte system. Oikos 117:754-762.

Kaunzinger, C.M.K. and P.J. Morin. 1998. Productivity controls food-chain properties in microbial communities. Nature 395:495-497.

Keats, R.A., L.J. Osher, and H.A. Neckles. 2004. The effect of nitrogen loading on a brackish estuarine faunal community: a stable isotope approach. Estuaries 27:460-471.

Kling, G.W. 1994. Ecosystem scale experiments: the use of stable isotopes in fresh waters. In Environmental Chemistry of Lakes and Reservoirs, ed.^eds. 91-120.

Lee, K.-S. and K.H. Dunton. 2000. Effects of nitrogen enrichment on biomass allocation, growth, and leaf morphology of the seagrass Thalassia testudinum. Marine Ecology Progress Series 196:39-48.

Martinetto, P., M. Teichberg, and I. Valiela. 2006. Coupling of estuarine benthic and pelagic food webs to land-derived nitrogen sources in Waquoit Bay, Massachusetts, USA. Marine Ecology Progress Series 307:37-48. 
McGlathery, K.J. 1995. Nutrient and grazing influences on a subtropical seagrass community. Marine Ecology Progress Series 122:239-252.

MCSM. 2001. Monroe County Stormwater Management Master Plan; Volume 1; Section 2.3; Pollution loads targets and analysis.

Parker, J.D., J.E. Duffy, and R.J. Orth. 2001. Plant species diversity and composition: experimental effects on marine epifaunal assemblages. Marine Ecology Progress Series 224:55-67.

Peterson, B.J., L. Deegan, J. Helfrich, J.E. Hobbie, M. Hullar, B. Moller, T.E. Ford, A. Hershey, A. Hiltner, G. Kipphut, M.A. Lock, D.M. Fiebig, V. McKinley, M.C. Miller, J.R. Vestal, R. Ventullo, and G. Volk. 1993. Biological responses of a tundra river to fertilization. Ecology 74:653-672.

Phillips, D.L. and J.W. Gregg. 2003. Source partitioning using stable isotopes: coping with too many sources. Oecologia 136:261-269.

Phillips, D.L. and P.L. Koch. 2002. Incorporating concentration dependence in stable isotope mixing models. Oecologia 130:114-125.

Polis, G.A. 1999. Why are parts of the world green? Multiple factors control productivity and the distribution of biomass. Oikos 86:3-15.

Posey, M.H., T.D. Alphin, L. Cahoon, D. Lindquist, and M.E. Becker. 1999. Interactive effects of nutrient additions and predation on infaunal communities. Estuaries 22:785-792.

Post, D.M. 2002a. The long and short of food-chain length. Trends in Ecology \& Evolution 17:269-277.

Post, D.M. 2002b. Using stable isotopes to estimate trophic position: models, methods, and assumptions. Ecology 83:703-718. 
Russell, B.D. and S.D. Connell. 2005. A novel interaction between nutrients and grazers alters relative dominance of marine habitats. Marine Ecology Progress Series 289:5-11.

Short, F.T., D.M. Burdick, and J.E. Kaldy. 1995. Mesocosm experiments quantify the effects of eutrophication on eelgrass, Zostera marina. Limnology and Oceanography 40:740-749.

Shurin, J.B., D.S. Gruner, and H. Hillebrand. 2006. All wet or dried up? Real differences between aquatic and terrestrial food webs. Proceedings of the Royal Society B-Biological Sciences 273:1-9.

Sierszen, M.E., G.S. Peterson, A.S. Trebitz, J.C. Brazner, and C.W. West. 2006. Hydrology and nutrient effects on food-web structure in ten Lake Superior coastal wetlands. Wetlands 26:951-964.

Singer, G.A. and T.J. Battin. 2007. Anthropogenic subsidies alter stream consumer-resource stoichiometry, biodiversity, and food chains. Ecological Applications 17:376-389.

Tewfik, A., J.B. Rasmussen, and K.S. McCann. 2005. Anthropogenic enrichment alters a marine benthic food web. Ecology 86:2726-2736.

Tewfik, A., J.B. Rasmussen, and K.S. McCann. 2007. Simplification of seagrass food webs across a gradient of nutrient enrichment. Canadian Journal of Fisheries and Aquatic Sciences 64:956-967.

Vander Zanden, M.J. and J.B. Rasmussen. 2001. Variation in $\delta^{15} \mathrm{~N}$ and $\delta^{13} \mathrm{C}$ trophic fractionation: Implications for aquatic food web studies. Limnology and Oceanography 46:2061-2066.

Vitousek, P.M., J.D. Aber, R.W. Howarth, G.E. Likens, P.A. Matson, D.W. Schindler, W.H. Schlesinger, and D.G. Tilman. 1997. Human alteration of the global nitrogen cycle: sources and consequences. Ecological Applications 7:737-750. 
Wear, D.J., M.J. Sullivan, A.D. Moore, and D.F. Millie. 1999. Effects of water-column enrichment on the production dynamics of three seagrass species and their epiphytic algae. Marine Ecology Progress Series 179:201-213.

Wootton, J.T., M.E. Power, R.T. Paine, and C.A. Pfister. 1996. Effects of productivity, consumers, competitors, and El Niño events on food chain patterns in a rocky intertidal community. Proceedings of the National Academy of Sciences of the United States of America 93:13855-13858.

Worm, B., H.K. Lotze, H. Hillebrand, and U. Sommer. 2002. Consumer versus resource control of species diversity and ecosystem functioning. Nature 417:848-851.

Zieman, J.C., J.W. Fourqurean, and R.L. Iverson. 1989. Distribution, abundance and productivity of seagrasses and macroalgae in Florida Bay. Bulletin of Marine Science 44:292-311. 
Table 1: Summary of producer and faunal group characteristics in control and enriched plots at Duck Key (nutrient-poor) and Nine Mile Bank (nutrient replete), modified from Gil et al. (2006). Faunal densities are given as the average $\# / 2 \mathrm{~m}^{2} \pm \mathrm{SE}$. "Other epifauna" consists primarily of bivalves and holothurians. Seagrass cover scores are on a Braun-Blanquet (BB) scale of 0 to 5 (Fourqurean et al. 2002).

\begin{tabular}{lcccr} 
& \multicolumn{2}{c}{ Duck Key } & \multicolumn{2}{c}{ Nine Mile Bank } \\
& Control & Enriched & Control & Enriched \\
Predatory crustaceans & $0.7 \pm 0.4$ & $3.0 \pm 1.4$ & $9.0 \pm 1.0$ & $11.7 \pm 1.6$ \\
Predatory fish & $4.0 \pm 0.5$ & $5.8 \pm 1.5$ & $1.2 \pm 0.5$ & $2.3 \pm 0.8$ \\
Other predators & $2.5 \pm 0.7$ & $3.5 \pm 1.2$ & $3.5 \pm 1.3$ & $4.0 \pm 1.1$ \\
Epiphyte grazing crustaceans & $23.8 \pm 4.6$ & $85.2 \pm 13.9$ & $29.2 \pm 7.0$ & $134.8 \pm 66.2$ \\
Epiphyte grazing gastropods & $1.3 \pm 0.7$ & $4.8 \pm 1.5$ & $10.3 \pm 2.4$ & $8.2 \pm 2.3$ \\
Benthic grazers & $14.0 \pm 3.8$ & $19.0 \pm 8.1$ & 0 & $0.2 \pm 0.2$ \\
Omnivores/scavengers & $15.0 \pm 1.8$ & $20.3 \pm 6.1$ & $27.2 \pm 6.2$ & $36.8 \pm 8.8$ \\
Other epifauna & $45.8 \pm 9.0$ & $43.8 \pm 3.7$ & $11.2 \pm 1.6$ & $17.8 \pm 5.2$ \\
Thalassia testudinum cover (BB score) & $3.7 \pm 0.2$ & $4.0 \pm 0.4$ & $4.3 \pm 0.3$ & $4.0 \pm 0.5$ \\
Halodule wrightii cover (BB score) & $0.1 \pm 0.1$ & $1.4 \pm 0.6$ & 0 & 0 \\
Epiphyte biomass $\left(\mu \mathrm{g}\right.$ chl $\mathrm{cm}^{-2}$ leaf) & $0.15 \pm 0.02$ & $0.32 \pm 0.05$ & $0.30 \pm 0.05$ & $0.19 \pm 0.03$
\end{tabular}


Table 2: Structure matrix of the correlations of predictor variables with discriminant functions. The strongest correlations for each discriminant function are indicated in bold type.

Predatory crustaceans

Other epifauna

Epiphyte grazing crustaceans

Predatory fish

Omnivores

Epiphyte grazing gastropods

Other predators

$\begin{array}{rc}1^{\text {st }} \begin{array}{c}\text { discriminant } \\ \text { function }\end{array} & \begin{array}{c}2^{\text {nd }} \text { discriminant } \\ \text { function }\end{array} \\ \mathbf{0 . 5 4 6} & 0.243 \\ \mathbf{- 0 . 4 0 5} & 0.189 \\ 0.077 & \mathbf{0 . 4 2 5} \\ -0.243 & \mathbf{0 . 3 1 1} \\ 0.179 & 0.180 \\ 0.260 & -0.063 \\ 0.057 & 0.090\end{array}$


Table 3: ANOVA table for the effects of nutrient enrichment and site on producer isotope signatures. Thalassia $\delta^{13} \mathrm{C}$ signatures were analyzed with a non-parametric Kruskal-Wallis test.

$$
\text { df } \quad \text { MS } F \quad p
$$

Thalassia testudinum

$\begin{array}{llrrrr}\delta^{15} \mathrm{~N} & \text { Site } & 1 & 142.26 & 60.92 & <0.0001 \\ & \text { Nutrient } & 1 & 60.44 & 25.88 & <0.0001 \\ & \text { Site x nutrient } & 1 & 4.59 & 1.96 & 0.1712 \\ & \text { Residual } & 30 & 2.34 & & \end{array}$

Green algae (excluding Halimeda)

$\begin{array}{llrrrr}\delta^{13} \mathrm{C} & \text { Site } & 1 & 0.20 & 0.08 & 0.7751 \\ & \text { Nutrient } & 1 & 0.01 & <0.01 & 0.9529 \\ & \text { Site } \mathrm{x} \text { nutrient } & 1 & 0.84 & 0.36 & 0.5553 \\ & \text { Residual } & 26 & 2.34 & & \\ \delta^{15} \mathrm{~N} & \text { Site } & 1 & 6.42 & 2.42 & 0.1321 \\ & \text { Nutrient } & 1 & 11.32 & 4.25 & 0.0494 \\ & \text { Site } \mathrm{x} \text { nutrient } & 1 & 0.06 & 0.02 & 0.8873 \\ & \text { Residual } & 26 & 2.66 & & \\ \text { Thalassia epiphytes } & & & & & \\ \delta^{13} \mathrm{C} & \text { Site } & 1 & 22.13 & 26.40 & 0.0021 \\ & \text { Nutrient } & 1 & 1.87 & 2.23 & 0.1856 \\ & \text { Site } x \text { nutrient } & 1 & 1.32 & 1.57 & 0.2565 \\ & \text { Residual } & 6 & 0.84 & & \\ \delta^{15} \mathrm{~N} & \text { Site } & 1 & 31.88 & 84.39 & <0.0001 \\ & \text { Nutrient } & 1 & 0.84 & 2.21 & 0.1874 \\ & \text { Site } x \text { nutrient } & 1 & 4.76 & 12.6 & 0.0121 \\ & \text { Residual } & 6 & 0.38 & & \end{array}$

Microbenthos

$\begin{array}{llrrrr}\delta^{13} \mathrm{C} & \text { Site } & 1 & 8.49 & 102.92 & 0.0002 \\ & \text { Nutrient } & 1 & 0.29 & 3.54 & 0.1186 \\ & \text { Site x nutrient } & 1 & 0.29 & 3.56 & 0.1177 \\ & \text { Residual } & 5 & 0.08 & & \\ \delta^{15} \mathrm{~N} & \text { Site } & 1 & 49.91 & 108.21 & 0.0001 \\ & \text { Nutrient } & 1 & 0.21 & 0.46 & 0.5288 \\ & \text { Site x nutrient } & 1 & 0.83 & 1.8 & 0.2372 \\ & \text { Residual } & 5 & 0.46 & & \end{array}$


Table 4: ANOVA table for the effects of nutrient enrichment and site on consumer isotope signatures.

\begin{tabular}{llrrrr}
\multicolumn{2}{l}{ Epiphyte grazers } & df & MS & $F$ & $p$ \\
$\delta^{13} \mathrm{C}$ & Site & 1 & 13.37 & 5.49 & 0.0242 \\
& Nutrient & 1 & 1.64 & 0.68 & 0.4162 \\
& Site x nutrient & 1 & 1.85 & 0.76 & 0.3890 \\
& Residual & 40 & 2.44 & & \\
$\delta^{15} \mathrm{~N}$ & Site & 1 & 68.62 & 94.68 & $<0.0001$ \\
& Nutrient & 1 & 6.34 & 8.74 & 0.0052 \\
& Site x nutrient & 1 & 0.31 & 0.43 & 0.5158 \\
& Residual & 40 & 0.72 & &
\end{tabular}

Omnivores/scavengers

$\begin{array}{rlrrrr}\delta^{13} \mathrm{C} & \text { Site } & 1 & 20.81 & 24.02 & <0.0001 \\ & \text { Nutrient } & 1 & 0.1 & 0.12 & 0.7353 \\ & \text { Site } x \text { nutrient } & 1 & 1.08 & 1.25 & 0.2681 \\ & \text { Residual } & 60 & 0.87 & & \\ \delta^{15} \mathrm{~N} & \text { Site } & 1 & 226.64 & 236.94 & <0.0001 \\ & \text { Nutrient } & 1 & 49.6 & 51.86 & <0.0001 \\ & \text { Site } x \text { nutrient } & 1 & 3.81 & 3.98 & 0.0504 \\ & \text { Residual } & 60 & 0.96 & & \end{array}$

Predators

$\begin{array}{rlrrrr}\delta^{13} \mathrm{C} & \text { Site } & 1 & 9.65 & 6.1 & 0.0199 \\ & \text { Nutrient } & 1 & 0.96 & 0.61 & 0.4415 \\ & \text { Site x nutrient } & 1 & 0.34 & 0.22 & 0.6454 \\ & \text { Residual } & 28 & 1.58 & & \\ \delta^{15} \mathrm{~N} & \text { Site } & 1 & 113.57 & 98.1 & <0.0001 \\ & \text { Nutrient } & 1 & 3.41 & 2.95 & 0.097 \\ & \text { Site x nutrient } & 1 & 1.52 & 1.31 & 0.2624 \\ & \text { Residual } & 28 & 1.6 & & \end{array}$


Table 5: Predictions of consumer diet composition from pooled community samples generated by concentration dependent mixing models at two sites in control and nutrient enrichment treatments.

$$
\text { Control Enriched }
$$

Duck Key

Epiphyte grazers

96\% Acetabularia

4\% Batophora

Predators

$70 \%$ Isopods

$26 \%$ Hermit crabs

$4 \%$ Carideans

Nine Mile Bank

Epiphyte grazers

Predators
47\% Halimeda

$46 \%$ Microbenthos

7\% Penicillus

92\% Hermit crabs

8\% Epiphyte grazing gastropods
50\% Batophora

37\% Acetabularia

$13 \%$ Penicillus

41\% Epiphyte grazing crustaceans

$37 \%$ Hermit crabs

22\% Epiphyte grazing gastropods

63\% Penicillus

21\% Halimeda

16\% Halodule

$61 \%$ Hermit crabs

$31 \%$ Epiphyte grazing gastropods

8\% Epiphyte grazing crustaceans 
Figure captions

Figure 1: Scores from linear discriminant function (DF) analysis based on epifaunal community composition at two sites in enriched and control plots of seagrass. The first DF primarily corresponds with differences between sites; the second DF corresponds with enrichment effects. Figure 2: Density of select epifaunal groups in control and enriched plots at Duck Key (nutrientpoor) and Nine Mile Bank (nutrient replete). Shown are epifaunal groups that were strongly correlated with (a) the first discriminant function, which corresponded with differences between sites, and (b) the second discriminant function, which corresponded with differences between enrichment treatments. Error bars depict SE. Modified from Gil et al. (2006).

Figure 3: Dual isotope graphs of all producers and consumers at (a) Duck Key (nutrient-poor) and (b) Nine Mile Bank (nutrient replete). Black symbols represent control plots; grey symbols represent enriched plots. Error bars depict SE. Arrows lead from control to enriched treatments for each consumer group.

Figure 4: Predictions of grazer diet composition from pooled community samples generated by simple mixing models at Duck Key and Nine Mile Bank in control and nutrient enrichment treatments: (a) epiphyte grazers and (b) benthic grazers. Error bars depict one SD and are calculated from the range of possible model output values. $\phi$ indicates insufficient grazer tissue for analysis.

Figure 5: Predictions of benthic predator diet composition from pooled community samples generated by simple mixing models at Duck Key and Nine Mile Bank in control and nutrient enrichment treatments. Error bars depict one SD and are calculated from the range of possible model output values. 
Figure 1

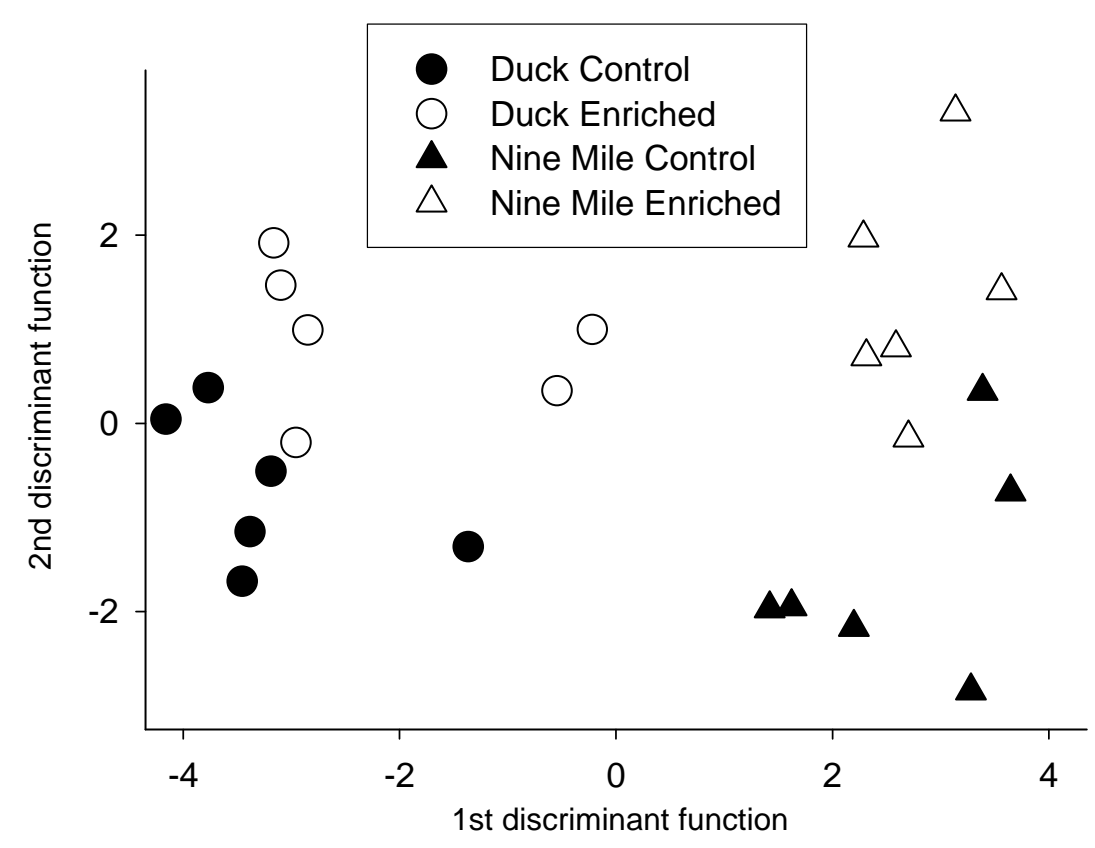


Figure 2
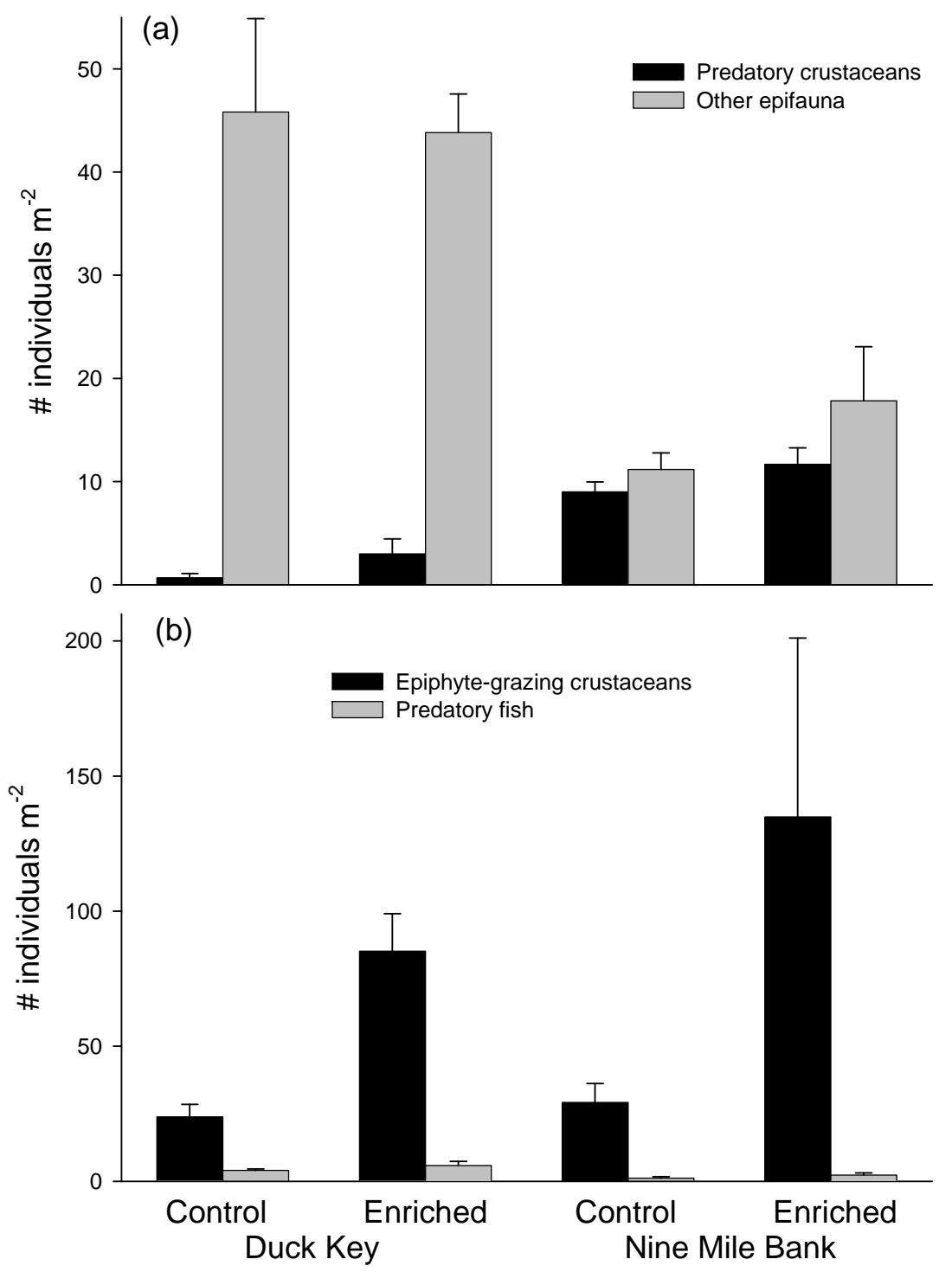
Figure 3
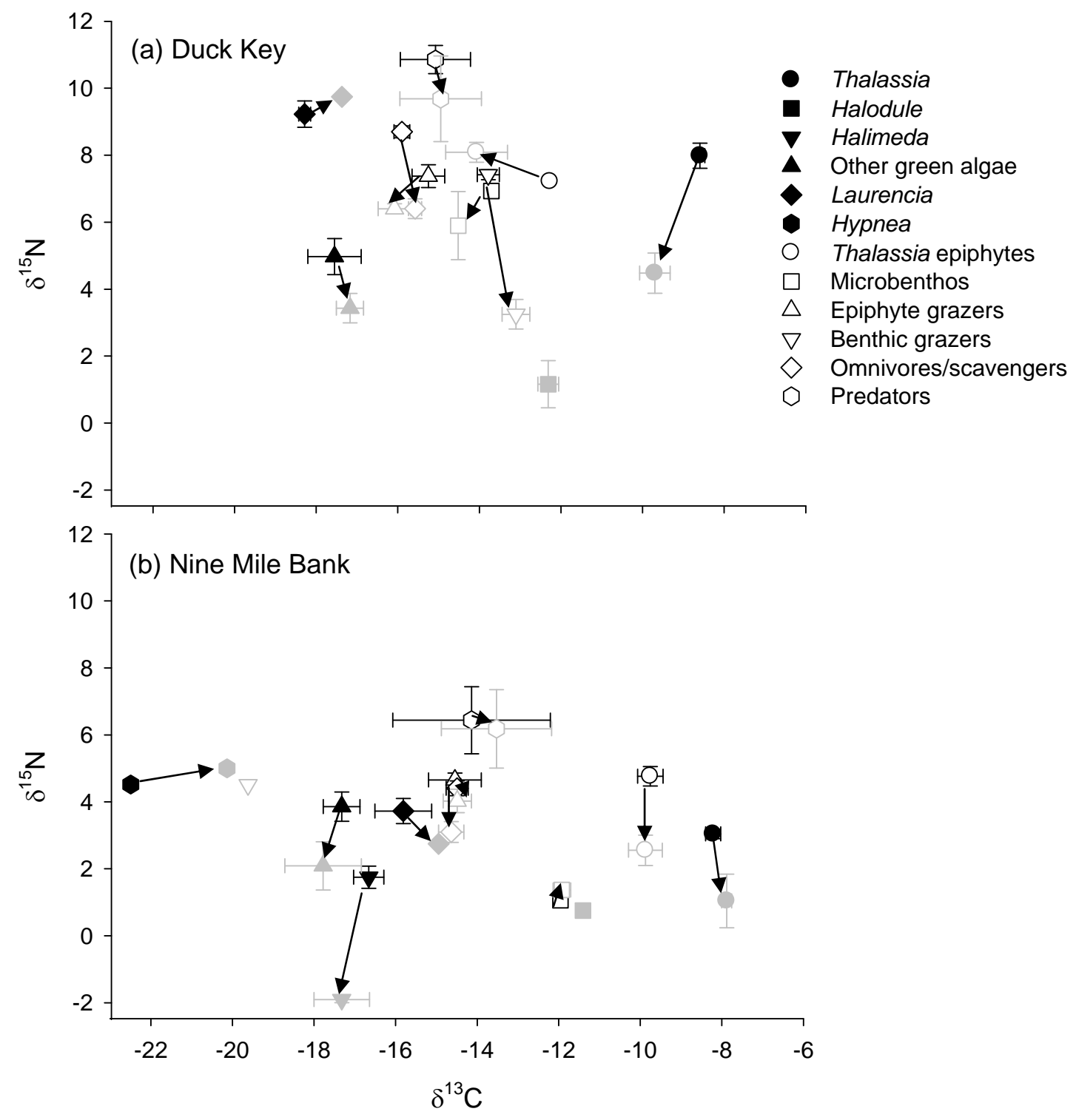
Figure 4

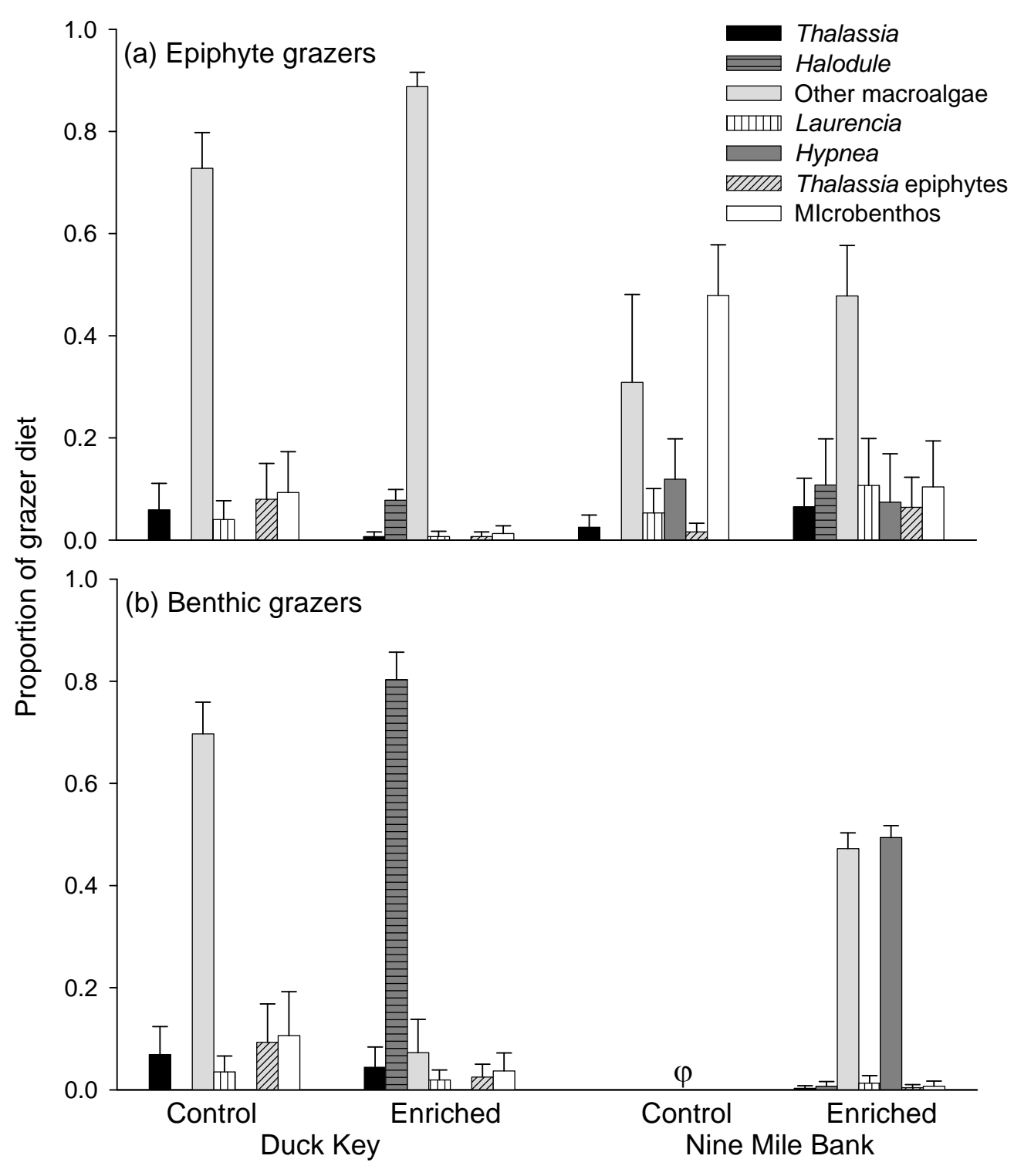


Figure 5

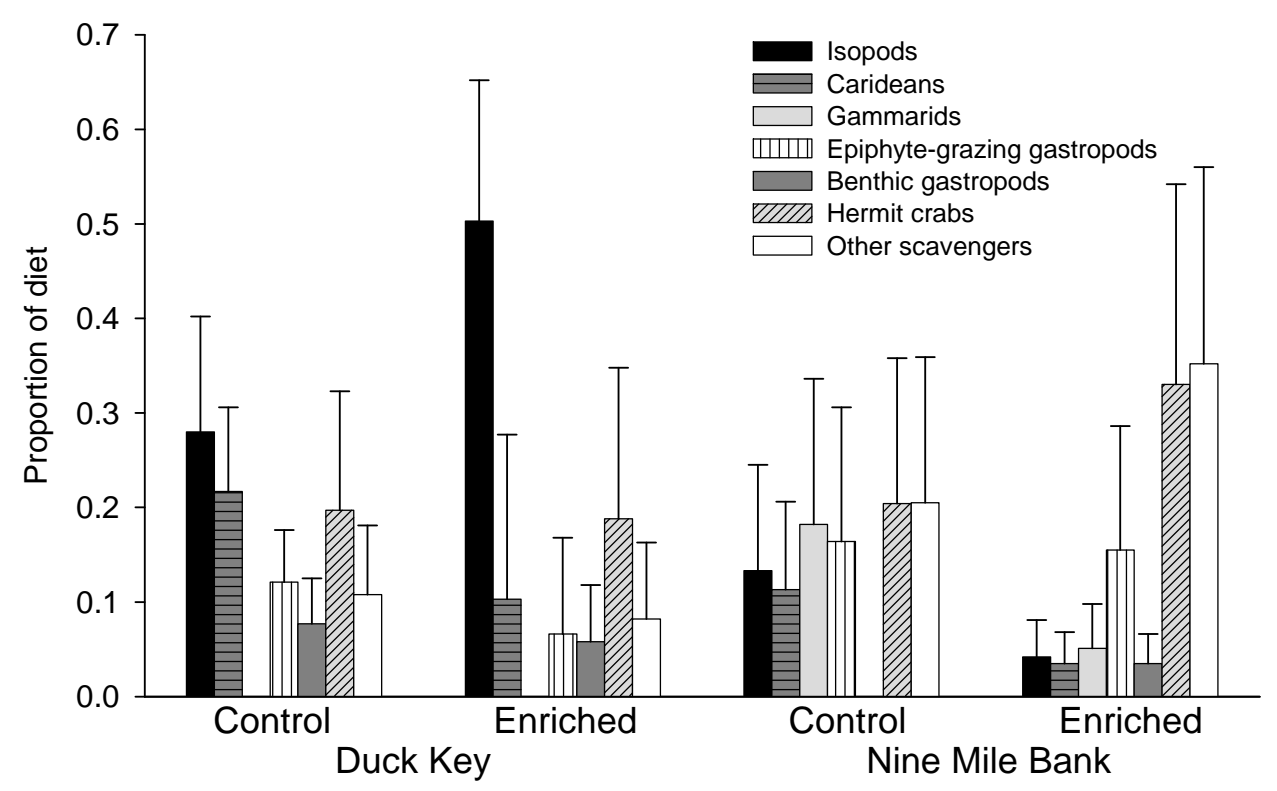


Digital Appendix A: Stable isotopic signatures of major producer and consumer groups at Duck Key (nutrient-poor) and Nine Mile Bank (nutrient replete). Values are averages \pm standard error; no SE is reported in cases where there was insufficient tissue for replicate measurements. -- denotes the absence of that trophic group.

\begin{tabular}{|c|c|c|c|c|c|c|c|c|}
\hline & \multicolumn{4}{|l|}{ Duck Key } & \multicolumn{4}{|c|}{ Nine Mile Bank } \\
\hline & \multicolumn{2}{|l|}{ Control } & \multicolumn{2}{|l|}{ Enriched } & \multicolumn{2}{|l|}{ Control } & \multicolumn{2}{|l|}{ Enriched } \\
\hline & $\delta^{13} \mathrm{C}$ & $\delta^{15} \mathrm{~N}$ & $\delta^{13} \mathrm{C}$ & $\delta^{15} \mathrm{~N}$ & $\delta^{13} \mathrm{C}$ & $\delta^{15} \mathrm{~N}$ & $\delta^{13} \mathrm{C}$ & $\delta^{15} \mathrm{~N}$ \\
\hline Thalassia & $-8.6 \pm 0.1$ & $8.0 \pm 0.4$ & $-9.7 \pm 0.4$ & $4.5 \pm 0.6$ & $-8.2 \pm 0.2$ & $3.0 \pm 0.1$ & $-7.9 \pm 0.1$ & $1.0 \pm 0.8$ \\
\hline Halodule & -- & -- & $-12.3 \pm 0.3$ & $1.2 \pm 0.7$ & -- & -- & -11.4 & 0.7 \\
\hline Halimeda & -- & -- & -- & -- & $-16.7 \pm 0.4$ & $1.7 \pm 0.3$ & $-17.3 \pm 0.7$ & $-1.9 \pm 0.1$ \\
\hline Other green algae & $-17.5 \pm 0.6$ & $4.9 \pm 0.5$ & $-17.1 \pm 0.3$ & $3.4 \pm 0.4$ & $-17.3 \pm 0.5$ & $3.8 \pm 0.4$ & $-17.8 \pm 0.9$ & $2.1 \pm 0.7$ \\
\hline Laurencia & $-18.3 \pm 0.1$ & $9.2 \pm 0.4$ & -17.3 & 9.7 & $-15.8 \pm 0.7$ & $3.7 \pm 0.4$ & -15.0 & 2.7 \\
\hline Hypnea & -- & -- & -- & -- & -22.5 & 4.5 & -20.2 & 5.0 \\
\hline Thalassia epiphytes & -12.3 & 7.2 & $-14.1 \pm 0.8$ & $8.1 \pm 0.3$ & $-9.7 \pm 0.3$ & $4.7 \pm 0.3$ & $-9.9 \pm 0.4$ & $2.5 \pm 0.5$ \\
\hline Microbenthos & -13.7 & 6.9 & $-14.5 \pm 0.1$ & $5.9 \pm 1.0$ & $-12.0 \pm 0.1$ & $1.0 \pm 0.1$ & $-12.0 \pm 0.2$ & $1.4 \pm 0.2$ \\
\hline Epiphyte grazers & $-15.3 \pm 0.4$ & $7.4 \pm 0.3$ & $-16.1 \pm 0.4$ & $6.4 \pm 0.1$ & $-14.5 \pm 0.6$ & $4.6 \pm 0.2$ & $-14.5 \pm 0.3$ & $4.0 \pm 0.3$ \\
\hline Benthic grazers & $-13.8 \pm 0.3$ & $7.4 \pm 0.1$ & $-13.1 \pm 0.3$ & $3.3 \pm 0.4$ & -- & -- & -19.7 & 4.5 \\
\hline Omnivores/scavengers & $-15.9 \pm 0.2$ & $8.7 \pm 0.2$ & $-15.6 \pm 0.2$ & $6.4 \pm 0.3$ & $-14.5 \pm 0.3$ & $4.4 \pm 0.2$ & $-14.7 \pm 0.3$ & $3.1 \pm 0.3$ \\
\hline Predators & $-15.1 \pm 0.9$ & $10.8 \pm 0.4$ & $-14.9 \pm 1.0$ & $9.7 \pm 1.3$ & $-14.1 \pm 1.9$ & $6.4 \pm 1.0$ & $-13.6 \pm 1.3$ & $6.2 \pm 1.2$ \\
\hline
\end{tabular}

